\title{
11. CUSTOMARY FAMILY LAW AND GENDER DISCRIMINATION IN PAPUA NEW GUINEA
}

\author{
By: Owen Jessep
}

\section{KEY TERMS AND PHRASES}

\section{(Gender) discrimination}

Discrimination is the act of treating things differently. Popularly discrimination is often used to refer to 'unfair' treatment, or treating people differently because of prejudice or irrelevant reasons. Gender discrimination specifically refers to treating men and women differently because of their gender and no other reason.

\section{Monogamy}

A condition or practice during which a person only has or is permitted one mate at any time.

\section{Patriarchal}

A patriarchal society popularly means a society in which men control a disproportionately large share of the power. When used in an anthropological sense patriarchy refers to a social organisation marked by the supremacy of the father in the clan or family, the legal dependence of wives and children, and the determination of descent and inheritance by the male line.

\section{Polygamy}

A situation in which a person may be married to more than one mate at the same time. It is not a gender specific term - a polygamous realtionship can be one in which a woman has more than one husband or a man has more than one wife. However, polygamy is often popularly used only to refer to a situation of polygyny, which is a situation in which a man can have more than one wife. 


\section{INTRODUCTION}

One of the continuing legal debates in Papua New Guinea in the years since Independence in 1975 has been the proper weight to be accorded to custom in the national legal system. At first glance, custom assumes a prominent position among the sources of law set out in the Constitution, as one of the two principal sources (together with common law) of what is called the 'underlying law'. ${ }^{1}$ Despite this there has been no shortage of complaints since 1975 as to the lack of progress in establishing and developing an appropriate "indigenous jurisprudence", that is, a body of legal doctrine which reflects Melanesian ideas and principles. ${ }^{2}$ The reasons for this situation are complex and the topic has been approached from different points of view. One persistent strand in the discussion has been the continued reliance of courts and lawyers on the imported common law. Relevant explanations for this phenomenon include the apparent ignorance or laziness or antipathy of expatriate lawyers and judges towards custom, ${ }^{3}$ the nature of education and training given to Papua New Guinean lawyers, ${ }^{4}$ and limitations relating to the adversarial trial process and judicial methodology. ${ }^{5}$

Another side to the debate, even in cases where the common law has not been directly involved, has been the tension and possible conflict between elements of custom and other legal principles, such as the human rights provisions set out in the Constitution. ${ }^{6}$ That is to say, the recognition of custom in a particular case is never automatic but is made subject to a number of constitutional or statutory restrictions and qualifications. In the field of customary family law, for example, these 'screening mechanisms' have assumed particular importance in the last decade, as Papua New Guinean courts have taken the initiative in challenging and refusing to recognise aspects of custom in individual cases relating to things such as marriage, divorce, and custody of children.

It is not possible in this chapter to consider all of these recent developments. Instead, I will focus on one matter in particular, which is also receiving attention in other parts of the Pacific and in numerous African jurisdictions; ${ }^{7}$ the conflict and interaction between customary family law, on the one hand, and constitutional or other legal provisions dealing with gender equality, on the other.

\section{OUTLINE OF CONSTITUTIONAL AND STATUTORY PROVISIONS}

By virtue of s 9 of the Constitution of Papua New Guinea, the laws of the country include the Constitution itself, various categories of legislation, and the 'underlying law'. According to s 20, until such time as an Act of Parliament provides otherwise, the underlying law is to be understood as set out in Schedule 2 of the Constitution. According to that Schedule, the two principal sources of the underlying law are custom $^{8}$ and the common law. ${ }^{9}$ In relation to custom, Sch 2.1(1), so far as relevant, states that 'custom is adopted, and shall be applied and enforced, as part of the underlying law'. This is however made subject to subsection 2 , which requires that 
the custom not be inconsistent with any constitutional law inconsistent with a statute or "repugnant to the general principles of humanity".

Another important statute dealing with custom is the Customs Recognition Act [Cap 19] (PNG). According to s 3(1) of this Act, custom may not be recognised or enforced in a particular case or context if to do so would result in injustice, would not be in the public interest, or would not be in the best interests of a child under the age of 16 years. The same statute, in s 5, provides (so far as relevant) that in a civil case, custom may be taken into account in relation to:

(f) marriage, divorce or the right to the custody or guardianship of infants, in a case arising out of or in connexion with a marriage entered into in accordance with custom.

In relation to customary marriage, it may also be noted that by virtue of s $3(1)$ of the Marriage Act [Cap 280] (PNG), a Papua New Guinean ${ }^{10}$ who is not already a party to a statutory marriage may enter a customary marriage in accordance with the custom of either of the parties. In this case, s 3(2) states that the customary marriage "will be valid and effectual for all purposes".

\section{Section 55 of the Constitution}

It follows from the constitutional and statutory provisions outlined above that there are a range of requirements that represent potential obstacles to the recognition and enforcement of family law and custom in a particular case. In practice these requirements may often overlap and the same arguments be used in relation to several of the grounds at the same time. For instance, the same considerations that are claimed to make a custom inconsistent with a provision of the Constitution or repugnant to the "general principles of humanity" may simultaneously found an argument that to enforce the custom would cause "injustice" "not be in the public interest" and so on. ${ }^{11}$ Examples of such alternative forms of argument will appear below. In what follows, however, I will concentrate on the ground of inconsistency with the Constitution, and in particular those provisions dealing with gender equality.

To begin with, there are relevant references in the 'National Goals and Directive Principles' (NGDP) in the Preamble to the Constitution, such as NGDP 2(5) which refers to "equal participation by women citizens in all political, economic, social and religious activities", and NGDP 2(12), to the effect that "a complete relationship in marriage rests on equality of rights and duties of the partners". Nevertheless, these NGDPs are made "non-justiciable" (which in effect means not directly enforceable by a court or tribunal) ${ }^{12}$ by s 25 (1) of the Constitution. More directly applicable is s 55 , dealing with the equality of citizens. This section reads as follows:

(1) Subject to this Constitution, all citizens have the same rights, privileges, obligations and duties irrespective of race, tribe, place of origin, political opinion, colour, creed, religion or sex.

(2) Subsection (1) does not prevent the making of laws for the special benefit, welfare, protection or advancement of females, children and young persons, 
members of under-privileged or less advanced groups or residents of less advanced areas.

(3) Subsection (1) does not affect the operation of a pre-Independence law.

One or two cases in the 1980's made passing references to s 55 in relation to custom, but without any serious discussion of the scope of this provision. For instance, in 1981 the Supreme Court had to consider the legality of sending PNG troops to Vanuatu for a peacekeeping operation. Michael Somare as leader of the Opposition had sought to challenge the constitutional validity of a parliamentary decision and an Act of Parliament approving the commitment of troops to Vanuatu. The Court's decision in Supreme Court Reference No 4 of $1980^{13}$ dealt merely with the preliminary issue of the petitioner's standing to challenge the actions of the Parliament. A majority of the Supreme Court held that the petitioner did have standing, based on his status as a Member of Parliament and as a citizen of Papua New Guinea. It is not necessary here to consider the reasoning of the judges, except to note that several of them refused to acknowledge the petitioner's claim to standing based on his position as a 'big man' according to custom. Of interest here is Kidu CJ's statement in response to this argument:

[Counsel for the petitioner] submitted that in Papua New Guinea 'big men' can speak in any forum. Mr. Somare should be allowed to speak in this forum because he is such a man. If this is so, it goes against s 55(1) of the Constitution:

Subject to this Constitution, all citizens have the same rights, privileges, obligations and duties irrespective of race, tribe, place of origin, political opinion, colour, creed, religion or sex..$^{14}$

This is an intriguing comment, but it is not clear which part of s 55 Kidu CJ had in mind. Since part of the petitioner's evidence was based upon custom in his home province, the Chief Justice may have simply had in mind differences based on "tribe" or "place of origin", that is, that this custom may have been different to those found in other parts of the country. On the other hand, Kidu CJ might have been objecting to a custom pertaining to 'big men' in contrast to women, that is that if men rather than women have a right of public audience this would be an example of discrimination on the basis of "sex". Since there was no real clarification of the point, this brief reference to s 55 unfortunately remains ambiguous.

Another judge in 1989 referred more clearly to s 55 as prohibiting discrimination between the sexes, but again in a context where detailed discussion was not necessary. In Bore Konia $v$ Daniel Dosinga and the State of $P N G^{15}$ Los J was hearing a claim for damages by a father whose son had been unlawfully shot by a police officer. The claim was based both on breach of the right to life guaranteed by the Constitution and on breach of custom. During the trial evidence was given as to the relevant custom in the deceased's area relating to compensation for wrongful death. Referring to this evidence, Los $J$ noted that the claim for customary compensation had now to be considered subject to the requirements of the constitutional framework. Thus: 
Killing as pay-back, based on the notion of an eye for an eye, and tooth for a tooth is unconstitutional... Giving away women as compensation cannot apply now because it is not only repugnant to the general principles of humanity but it is in breach of specific sections of the Constitution. A woman is a person not a property. As a person she has the same rights as a man... Section 55(1) summarizes it all...

I am aware that equality of women does not go down well with a traditional PNG man, but he has to accept that, that is the position that he himself through the Constituent Assembly accepted at Independence...

By our Constitution all lives are equal. They are not graded according to gender, social or official status. See s 55(1) of the Constitution cited earlier. The amount of compensation paid for loss of life must be equal whether a person is a man or woman, big man or little man. ${ }^{16}$

The judge proceeded, without quantifying the damages in his judgment, to find the first defendant liable, and the state of PNG vicariously liable for the wrongful actions of the first defendant.

\section{CUSTOMARY FAMILY LAW CASES AND SECTION 55}

In the early 1990's, a number of cases arose in which the National Court felt obliged to intervene to protect women from excessive punishment at the hands of village courts. ${ }^{17}$ One such case was the 1991 decision of Re Wagi Non and the Constitution Section 42(5). ${ }^{18}$ The husband had left his wife and their four children in the care of his relatives in his village when he travelled to another province for employment. After he had been away for five or six years without making contact with his family or relatives the wife eventually formed a relationship with another man. The husband's relatives then complained in the Village Court that the wife had committed adultery, in breach of customary expectations, and obtained an order for compensation against her. When she failed to pay the amount required, the Village Court ordered her imprisonment. In the National Court, Woods J ordered her release, stating (among other reasons) that the custom relied on by the relatives of the husband should not be recognised, as it infringed s 55 of the Constitution. In the opinion of the Court:

I cannot help feeling that the going off and leaving the wife and children without his support and protection yet expecting her to remain bound by custom is a custom that must be denigrating to her status as a woman. It is denying her the equality provided in the Constitution, s 55... I am not saying that a man cannot have several wives and cannot travel but if he chooses to have wives and travel elsewhere he must accord them equality in care and participation and she must have the same freedoms that he has... The facts of this case suggest that this woman is bonded, almost in slavery, to the husband even when the husband neglects her. This must clearly be a denigration of the woman's humanness. ${ }^{19}$ 
A similar result was reached by Woods J on almost identical facts in Re Kaka Ruk and the Constitution Section 42(5), ${ }^{20}$ although, there, the Court preferred to ground the decision on the doctrine of "repugnancy to the general principles of humanity". ${ }^{21}$

Returning to s 55, in Re Kepo Raramu and the Yowe Village Court, ${ }^{22}$ a Village Court had sentenced a woman to a term of six months' imprisonment for commencing a new relationship after her husband had died. On appeal, the National Court ordered her immediate release. One of the several grounds relied on for this decision by Doherty J appears in the following passage:

I am well aware of the custom in many areas that says women whose husbands have died are not to go around with another man... I do not know of any equivalent custom that says a man whose wife has died is not allowed to go around with other women, and, as such, I consider this custom strikes against the basis of equality provided in s $\mathbf{5 5}$ of the Constitution.

It appears to me, to quote the words of [Kidu CJ], 'it is a custom that is oppressive to women', and the Village Court is in error in upholding this custom. ${ }^{23}$

Other village court decisions, such as those concerning the law of customary divorce, have also been the subject of National Court appeal cases. Some of these decisions were made by the judge in the role of prison visitor and the judgments are rather cursory and have not been reported. The former Chief Justice, Kidu CJ, heard several cases in 1991 in which he asserted the freedom of wives to leave their husbands regardless of any rule of custom to the contrary. One example is that of Re Raima and the Constitution Section 42(5). ${ }^{24}$ There, a woman had been imprisoned by a Village Court after being unable to pay the 300 kina $^{25}$ compensation ordered in favour of her former husband, whom she had left. Kidu CJ upheld several objections to both the compensation order and the sentence of imprisonment. After examining the Village Court records, the Chief Justice stated:

The order does not say why the compensation was ordered to be paid by her. Was it to be paid because she broke the marriage or was it to be repayment of the bride price paid for her by the husband of 3-4 months? On the face of it, it would appear to be merely for her speaking strongly of breaking her marriage. This is, of course, wrong in law. Whether under introduced law or customary law a woman has the right to break her marriage. It is her right and she should not be penalized for this. If a woman breaks her marriage the village court only has the right to consider the repayment of bride price according to customary law. A village court has no power to penalize her for breaking the marriage. ${ }^{26}$

Although the basis for this decision is not spelt out in the brief judgment, it is likely that considerations of equality between the sexes were in the mind of Kidu CJ. The clear implication of his statement is that any custom which denied the woman the right of divorce would not be recognised and any court order enforcing such a custom would similarly be invalid.

Unlike the cases considered so far, in which National Court judges were responding to what they saw as the excesses and misuse of jurisdiction by village court 
magistrates, the 1997 case of $R e$ Willingal $^{7}$ reached the National Court after publicity in one of Papua New Guinea's national newspapers. ${ }^{28}$ In response to the newspaper article, National Court proceedings were instituted by a nongovernmental human rights organisation, the Individual and Community Rights Advocacy Forum. The proceedings featured a whole battery of legal challenges against a custom requiring a woman's forced marriage. The unfortunate woman was Ms Miriam Willingal, an 18 year old high school student from the Western Highlands area of Papua New Guinea, who was being made the unwilling participant in a complicated compensation settlement between two kin groups.

It is not necessary here to set out the full facts of the case, which began with the death of Miriam's father, who appeared to have been the innocent victim of a police raid on a Highlands village. For various reasons this then led to extended negotiations between the members of his kin group (to which Miriam also belonged) and the kin group of his mother, two clans which had for generations enjoyed a close relationship. At issue was the question of how to restore the balance between the two groups in order to ensure their continued co-existence and alliance in the future.

At the trial there was some disagreement over the details of the customary compensation claim. The broad outlines of the claim referred to 25 pigs, 20,000 kina and two women. ${ }^{29}$ Some witnesses said that no particular women were identified in the negotiations, that no woman would be pressured to comply with the arrangement, and that the marriages might not take place until some years in the future. Other witnesses, including Miriam, gave a contrary impression, to the effect that pressure could be or had been brought to bear on individual women by the clan leaders, and that a delay in arranging the marriages would cause aggravation and ill feeling between the two groups. On this crucial point Injia J found that Miriam had already been subjected to pressure, that she did not like the idea of being used as a form of payment and that she was afraid that the men of both clans might become impatient and try to force her to accept the planned marriage. ${ }^{30}$

Turning to the relevant law Injia J had no doubt that Miriam's constitutional rights had been infringed and gave multiple reasons for this conclusion. His general approach to the issue of recognition of custom appears in the following passage:

The traditional customs of the people of [this area] like the rest of PNG have existed from time immemorial and they serve complex value systems which only they themselves best know. It is not easy for any outsider to fully understand the customs and the underlying values and purposes they serve. Any outsider including the modern courts must not be quick to extract those customs and their values and pass judgments on their soundness or otherwise... But it is clear to me that the framers of our Constitution and modern day legislators were thinking about a modern PNG based on ethnic societies whose welfare and advancement was based on the maintenance and promotion of good traditional customs and the discouragement and elimination of bad customs as seen from the eyes of an ordinary modern Papua New Guinean. No matter how painful it may be to the small ethnic society concerned, such bad custom must give way to the dictates of our modern national laws. ${ }^{31}$ 
The Court accordingly held that a number of provisions of the Constitution and of other statutes would be infringed were the custom to be enforced. These included constitutional guarantees of sexual equality, about which Injia J had this to say:

It is further submitted that to oblige or pressure a woman to marry someone from another tribe against her will restricts her right to freedom to choose a partner in marriage on equal terms with men. It is submitted that this is contrary to Constitution, National Goals and Directive Principles No 2(5) and (12)... I agree with these submissions...

It is submitted that the same custom infringes Section 55 in that it violates the equal choice that a woman in [this area], in this case Miriam, had of choosing a partner from anywhere in Papua New Guinea just like men from [her] tribe and the [other] tribe. I accept this submission. There is no evidence that the same custom which targets young women from [Miriam's] tribe also targets eligible men from the [other] tribe. ${ }^{32}$

For these and numerous other reasons, the court then proceeded to issue permanent injunctions and restraining orders against the various groups and their members.

\section{DISCUSSION}

I have outlined a number of cases arising in the last decade in Papua New Guinea in which the courts have been prepared to strike at aspects of customary family law. These cases have variously concerned differing expectations about spousal behaviour in a customary marriage, parental custody rights, customary divorce, proper behaviour as a widow and forced marriage. Section $\mathbf{5 5}$ of the Constitution, among other provisions, has been invoked against customs which appeared to the courts to be one-sided, oppressive or patriarchal in their application, and therefore to be unlawful examples of gender discrimination. It is fair to say, however, that the discussion in these cases of the notion of 'discrimination', and of the proper scope and meaning of s 55 , remains at a relatively simple and straightforward level..$^{33}$

This is not to say that the judges in these cases should have been expected to engage in a lengthy theoretical analysis. After all, judges obviously respond primarily to the arguments presented to them. In few of the cases has there been much if any attempt to justify or provide supporting arguments for the custom in question. Nor has the court been requested to attempt an overall assessment of the relationship between those parts of the Constitution emphasising the importance of custom and the provisions dealing with rights of equality. Is it possible to reconcile these provisions, or should one set of provisions always take precedence over the other? Could a court in a particular case be asked to engage in a balancing exercise, weighing up the benefits and values of the customary principles and concepts, on the one hand, and the equality rights of men and women, on the other?

As to the interpretation of s 55 , there has also not been any attempt to date to uphold elements of family law custom by reference to s $55(3)$, which states that the nondiscrimination principle in subsection (1) "does not affect the operation of a pre- 
Independence law". The expression "pre-Independence law" is defined in Sch 1.2 of the Constitution to have the same meaning as in Sch 2.6 (on the adoption of preIndependence laws), which defines the term to refer exclusively to statute law. At first glance, therefore, a custom which existed prior to Independence would not gain any special protection from subsection (3). On the other hand, what if the custom in question was recognised and validated by a pre-Independence (that is, pre-1975) statute? Two such provisions relating to customary marriage have been referred to earlier, namely s 5(f) of the Customs Recognition Act (first passed in 1963, now Cap 19 of the Revised Laws), and s 3 of the Marriage Act (also first passed in 1963, now Cap 280 of the Revised Laws). By virtue of the former, custom may be "taken into account" in relation to a marriage, and the latter provision states more specifically that a marriage entered into in accordance with the relevant custom "is valid and effectual for all purposes". Could it be argued, then, that an otherwise discriminatory feature of customary marriage law would thereby be protected, via subsection (3), from challenge under s $55(1)$ ?

Questions of this sort would no doubt arise if it were sought to challenge fundamental elements of the system of customary marriage in Papua New Guinea. In recent years, the most controversial family law topic has been that of polygamous marriage. Even more than the constant controversy over elements of customary brideprice, ${ }^{34}$ the practice of polygamy (which in practice means polygyny, that is the right of a man to have more than one customary wife) has produced a constant flow of public debate. ${ }^{35}$ While polygamy is virtually unknown in many parts of the country today, it remains a relatively common practice among leaders from the Highlands provinces. One memorable example of the public interest in polygamy is the controversy which erupted when a newly-appointed Governor-General decided to prefer the younger of his two wives to accompany him to England to receive his knighthood, and then to occupy the viceregal residence with him. ${ }^{36}$

In legal terms, a polygamous customary marriage has generally been regarded as valid by virtue of s 3 of the Marriage Act [Cap 280] (PNG), referred to earlier. Thus, in the passage previously quoted from Re Wagi Non and the Constitution Section 42(5), ${ }^{37}$ Woods J stated plainly: "I am not saying that a man cannot have several wives...", but went on to insist that all the wives must be treated fairly and equally.

Against advocates of the practice, who rely on the Constitution's support for traditional customs, objections have come from community and church groups as well as magistrates and judges dealing with the frequent financial and custody disputes, criminal assaults and murders (whether between spouses, or between cowives) arising from polygamous arrangements. ${ }^{38}$ Since 1996, private members' bills designed to abolish or ban polygamy have been circulated on several occasions in Parliament, so far without any collective governmental response.

In the absence of any legislative initiative it is interesting to speculate on whether a court in Papua New Guinea might be faced with an objection to some aspect of customary polygamous marriage. While an out-and-out constitutional challenge to the custom is theoretically possible, it is far more likely that the issue would arise in 
the circumstances of an everyday case. Such a claim might be raised in any context in which a party's rights or responsibilities will vary according to whether the marriage is legally valid or not (such as spousal maintenance, property claims, inheritance, compensation in relation to fatal accidents and so on). The contending party, then, could be a husband, a wife, a relative, an insurance company or anyone else with an interest in the result of the litigation.

Some years ago, it should be noted, a Task Force of the PNG Law Reform Commission expressed the view that the custom of polygamy was "unconstitutional", because the freedom to have more than one spouse was only extended to males. Rather than argue for a similar liberty to be extended to females, however, the Task Force concluded that Parliament should insist on monogamy for everyone. ${ }^{39}$

In its claim that polygamy was unconstitutional, the Task Force presumably had in mind the prohibition on discrimination contained in s 55 of the Constitution. An alternative form of the same argument might focus on the imbalance in the respective rights and responsibilities expected from each spouse in relation to the other. While it can be argued, as Kaganas and Murray have attempted in the African context, ${ }^{40}$ that:

The treatment of women as property, sexual stereotyping and domination are not limited to polygamy, nor are they practices that can be shown to be inevitable in polygamy...

the approach and judicial logic consistently demonstrated by the National Court judges in the cases outlined earlier, culminating in the 1997 case of Re Willingal, would suggest that the customary incidents of a polygamous marriage in Papua New Guinea typically infringe the right to sexual equality in s 55(1). If so, then the court would have to give consideration to s $55(3)$, as to whether the custom could be saved as depending upon a "pre-Independence law".

Of course, leaving aside these complications surrounding the proper interpretation of s 55, it is clear that some of the other grounds canvassed above could also come to the fore here: for instance, that customary expectations and practices relating to polygamy in a particular Papua New Guinean community might be inconsistent with other rights guaranteed by the Constitution, might produce injustice, or might be contrary to the public interest (see Customs Recognition Act [Cap 19] (PNG), s 3). A court's decision invalidating, on any of the grounds mentioned, a particular polygamous marriage (that is, by denying recognition and enforcement to the relevant custom) would not automatically spell invalidity for all polygamous marriages, but would obviously have significant implications for other cases. Alternatively, such a decision might prompt further calls for legislative intervention. ${ }^{41}$

\section{CONCLUSION}

It has been frequently argued that many aspects of customary family law in Papua New Guinea reflect entrenched gender discrimination against women. ${ }^{42}$ Whether referring generally to the law of customary marriage and divorce, or to the extremely high incidence of domestic assaults and sexual violence reported for many parts of the 
country ${ }^{43}$ these commentators would certainly agree with the views of Los $\mathrm{J}$, expressed in a different context some years ago:

Although the equality of sexes is now a constitutional principle in Papua New Guinea, at this stage it is more a matter of books, rather than practice. The character of all aspects of life is a male dominance. ${ }^{44}$

In this chapter, I have outlined some of the tensions and possibilities for conflict between constitutional norms that incorporate custom as part of the law of the country, and other constitutional provisions that support the principles of gender equality. In the last decade, National Court judges have begun to take the initiative in challenging aspects of customary family law, by refusing to acknowledge and enforce elements of custom which are found to denigrate or oppress women. This has been especially evident in relation to custom as reflected and purportedly implemented in decisions of village courts in some provinces. In overturning such decisions, the National Court judges have employed a variety of judicial weapons, among them s $\mathbf{5 5}$ of the Constitution.

Of course, there is no reason to think that orders of the National Court immediately bring about changes in ideas and behaviour among the people concerned, ${ }^{45}$ and it is very likely that similar cases will continue to arise in the future. Were such cases to go further and question more fundamental characteristics of the system of customary marriage (such as polygamy or brideprice), the courts would then be faced with the task of analysing the concepts of gender equality and discrimination, and the interpretation of s 55 , in a more detailed way than has so far proved to be necessary. 


\section{ENDNOTES}

1 See Constitution of Papua New Guinea, ss 9, 20, and Sch 2. See also Underlying Law Act 2000 (PNG).

2 "Indigenous jurisprudence" is the expression used in s 21(1) of the Constitution.

3 For an early example, see Weisbrot, D. 1982. The Impact of the Papua New Guinea Constitution on the Recognition and Application of Customary Law. In Sack, P. (ed.) Pacific Constitutions. Canberra: Research School of Social Sciences, Australian National University.

4 See, for example, Nonggorr, J. 1993. Development of Customary Law: Replacing the Customs Recognition Act. Melanesian Law Journal 21: 49-62.

5 See, for example, Amet, A. 1995. Severing the Umbilical Cord from the Common Law. In Aleck, J. \& Rannells, J. (eds.) Custom at the Crossroads. Port Moresby: Faculty of Law, University of Papua New Guinea.

6 It may be noted that while Papua New Guinea has ratified certain international human rights instruments such as the Convention on the Elimination of Discrimination against Women (ratified in January 1995) and the Convention on the Rights of the Child (ratified in March 1993), these instruments do not have effect as domestic law within Papua New Guinea. This would only be the case if the Conventions were specifically implemented by national legislation.

7 In relation to current debates in Southern Africa, for example, see Nhlapo, T. 1994-95. Indigenous Law and Gender in South Africa: Taking Human Rights and Cultural Diversity Seriously. Third World Legal Studies 1994-95: 49-71; Letuka, P. \& Armstrong, A. 1996 Which Law? Which Family? Which Women? - Problems of Enforcing CEDAW in Southern Africa. In Lowe, N. \& Douglas, G. (eds.), Families Across Frontiers. The Hague: Nijhoff; Fishbayn, L. 1999. Litigating the Right to Culture: Family Law in the New South Africa. International Journal of Law, Policy and the Family 13: 147-73.

8 In Sch 1.2 of the Constitution, the term 'custom' is defined to mean: "the customs and usages of indigenous inhabitants of the country existing in relation to the matter in question at the time when and the place in relation to which the matter rises, regardless of whether or not the custom or usage has existed from time immemorial".

9 By Sch 2.2 of the Constitution, 'common law' here means "the principles and rules of common law and equity in England" as at Independence Day (16th September 1975).

10 As an indication of how little has changed in the years since Independence, the statute in fact still uses the colonial expression 'native', which would today be understood to mean 'automatic citizen' (as defined in the Constitution, s 65).

11 The case of Re Willingal (1997) N 1506, to be referred to below, provides an excellent example.

12 Constitution, Sch 1.7.

13 [1981] PNGLR 265.

14 [1981] PNGLR 265, at 271.

15 (1989) N 745. 
16 (1989) N 745, at 8, 14. Similar sentiments were expressed by Kidu CJ, apparently in relation to the 'repugnancy' doctrine, in the case of State $v$ Nerius and Tingas (1982) N 397. There, two Baining men (East New Britain Province) charged with rape pleaded as an excuse that they were obliged to commit the rape by their custom of payback. Custom has never been accepted in Papua New Guinea as a complete defence to a criminal charge, although it may be taken into account in determining sentence (Customs Recognition Act [Cap 19] (PNG), s 4). Kidu CJ (at 3) was not impressed with the defendants' argument: "If this is a custom of the Baining people then it is repugnant to the dictates of Papua New Guinea's Constitution. Women/girls... are not "things" or "chattels" to be dealt with by men as they wish. Any custom which says that if A rapes B's sister, B is entitled to rape A's sister cannot be condoned by the Courts... Women are equal to men in Papua New Guinea under our Constitution. They must be so treated by men".

17 See Jessep, O. 1992. Village Courts in Papua New Guinea: Constitutional and Gender Issues. International Journal of Law and the Family 6: 401-16.

18 [1991] PNGLR 84. For a thoughtful discussion of this case, see Zorn, J.G. 1994-95. Women, Custom and State Law in Papua New Guinea. Third World Legal Studies 1994-95: 169-205.

19 [1991] PNGLR 84, per Woods J at 86-87.

20 [1991] PNGLR 105.

21 Another illustration of the use of the 'repugnancy' doctrine is found in the 1994 case of Ubuk v Darius [1994] PNGLR 279. This was a dispute over custody of a child aged 20 months, whose parents had lived together in a de facto relationship for about two years. When the relationship broke up, the man (who had been previously married by custom) returned to live with his customary wife and their children. He sought custody of the exnuptial daughter, and emphasised his wife's apparent willingness to look after her. He relied on evidence of local custom to the effect that if an informal relationship did not progress to the status of a customary marriage, the father was entitled to automatic custody of any child born in the meantime, subject to a payment of compensation to the woman for having borne the child. The Court was not impressed with the argument, and gave custody of the child to the mother, with access rights to the father. In the words of Sevua J (at 283-84): "Whether one views it subjectively or objectively, the woman is a sex object. So where is the morality and value of humanity in this woman?... How does a woman in such a situation free herself from this seemingly sexual domination? I consider [these] customs repugnant to the general principles of humanity and, therefore, inapplicable to the present case. The applicant can gain no assistance from that customary law".

22 [1994] PNGLR 486.

23 [1994] PNGLR 486, per Doherty J at 486. Another of the grounds upheld was that there was no such offence prescribed as part of the Village Court's criminal jurisdiction.

24 Unreported, National Court, Mt Hagen Western Highlands Province, 15th April 1991.

25 At this time the kina was approximately equal to AU\$1.33.

26 See above, $\mathrm{n} 24$ at $\mathrm{p} 1$.

27 Re Willingal (1997) N 1506. 
28 As is mentioned in the judgment of Injia J, (1997) N 1506 at 7, the PNG Post Courier of 3 May 1996 contained an article with the headline "Girl Sold in Death Compensation". For comment on the case, see Mydans, S. 1997 When the Bartered Bride Opts out of the Bargain. New York Times, 6 May 1997, p A4; and Gewertz, D. \& Errington, F. 1999. Emerging Class in Papua New Guinea: The Telling of Difference. Cambridge: Cambridge University Press, ch 6.

29 (1997) N 1506, at 24. At this time, the value of the kina was approximately equal to AU\$0.92.

30 See above, n 27, at p 42 .

31 See above, n 27, at pp 51-52, 54-55.

32 See above, n 27, at pp 47-49.

33 Zorn, J.G. 1994-5. Above, n 18 at p 179: "But discrimination means more than merely differential treatment. Feminist theory, for the most part, applauds the recognition of difference. It is only when differences are used to promote inequality, when difference is used as the excuse for permitting one group access to desired goods and statuses and denying access to another group, that discrimination can be said to exist." For some useful treatments of the concept of discrimination in the context of the new South African Constitution, which is of relevance to the Papua New Guinean situation, see Liebenberg, S. (ed) 1995. The Constitution of South Africa from a Gender Perspective. Cape Town: Community Law Centre.

34 On brideprice, see Jessep, O. \& Luluaki, J. 1994. Principles of Family Law in Papua New Guinea ( $\left.2^{\text {nd }} \mathrm{ed}\right)$. Port Moresby: UPNG Press, ch 2, pp 17-20, 80-85.

35 For discussion, see for example Jessep, O. 1993. The Governor-General's Wives Polygamy and the Recognition of Customary Marriage in Papua New Guinea. Australian Journal of Family Law 7: 29-42. Analogous contemporary discussions in various African jurisdictions are referred to in the articles mentioned at n 6 above, and other papers in Eekelaar, J. and Nhlapo, T. (eds.) 1998. The Changing Family - Family Forms and Family Law. Oxford: Hart.

36 Jessep, O. 1993. Above, n 35.

37 [1991] PNGLR 84, per Woods J at 86-87.

38 Among the frequent references in the press, the Catholic Church of PNG has recently called for "a total ban on polygamy" (PNG Post Courier, 21st April 1999), and a National Court judge has called for legislation to punish husbands when co-wives are led to injure or kill one another (PNG Post Courier, 7th May 1999).

39 PNG Law Reform Commission, Task Force on Family Law Reform, Press Release, 20th June 1990.

40 Kaganas, F. Z \& Murray, C. 1991. Law, Women and the Family: The Question of Polygyny in a new South Africa. Acta Juridica 116-34, at 128. Even so, they go on to say (p 128) that "Nevertheless, it is extremely difficult to disassociate these practices from polygyny or to envisage a polygynous household in which the husband does not dominate".

41 On the difficulties inherent in any legislative attempt to ban or discourage polygamy, see Jessep, O. 1993. Above, n 35 at pp 40-41. 
42 See, for example, Johnson, D. 1979. Aspects of the Legal Status of Women in Papua New Guinea in Melanesian Law Journal Vol 7: 5-81, at p 33; PNG Law Reform Commission 1992. Final Report on Domestic Violence: Report No 14 PNGLRC: Port Moresby, at p 22; Toliman, M., Davani, C. \& Passingan, L. 1994. Papua New Guinea in Women and Law in the Pacific - Report of a Regional Seminar International Commission of Jurists: Suva; Doherty, T. 1999. International Standards, Domestic Litigation and the Advancement of Women's Rights: Perspectives and Experiences from the South Pacific. Adams, K. Byrnes, K. \& A. (eds.) Gender Equality and the Judiciary. London: Commonwealth Secretariat, at pp 135-38. See also Zorn, J.C. 1994-95, Above, n 18 at pp 202-204.

43 See, for example, PNG Law Reform Commission, above n 43; and Dinnen, S. \& Ley, A. (eds.) 2000 Reflections on Violence in Melanesia. Sydney: Hawkins and Asia Pacific Presses.

44 State v Kopilyo Kipungi and others (1983) N 437, at 5.

45 For example, in the year following the decision in Re Willingal (1997) N 1506 (the case of Miriam, discussed above), the PNG Post Courier carried a front page story with the headline "Clan Gives Girls Away In Compo Settlement" (7th August 1998). The item, by W. Palme, told of a death compensation negotiation between two clans in the Western Highlands. The original claim was for 30 pigs and 30,000 kina, subsequently changed to 30 pigs, 20,000 kina, and two 16-year-old women. A judicial inquiry was ordered into the matter, but the outcome was never reported in the newspaper. 


\section{Review questions}

1. Do the people of your jurisdiction tend to view 'human rights' as being opposed to 'custom'? Do you?

2. Why do you think that human rights and custom seem to clash so much?

3. What areas other than women's rights do you think create the most clashes between constitutionally enshrined human rights and custom?

4. Human rights are often viewed as being 'natural'. Do you agree with this viewpoint? Why/why not? What other aspects of your countries legal and social systems do people treat as being 'natural? Are they actually natural?

\section{Further readings}

Aleck, J. \& Rannells, J. (eds) 1995. Custom at the Crossroads. Port Moresby: Faculty of Law UPNG.

Barber, B. 1995. Jihad vs McWorld: How globalism and tribalism are reshaping the world. New York: Ballantine Books.

Dunne, T. \& Wheeler, T. 1999. Human Rights in Global Politics. Cambridge:

Cambridge University Press.

Ishay, M. (ed) 1997. The Human Rights Reader: Major political essays, speeches and documents from the Bible to the present. New York \& London: Routledge.

Sheleff, L. 1999. The Future of Tradition: Customary Law, Common Law and Legal Pluralism. London: Frank Cass.

Sperber, D. 1996. Explaining Culture: A naturalistic approach. Oxford: Blackwell Publishers.

Weeramantry, C.G. 1982. An Invitation to the Law. Australia: Butterworths. 